Article

\title{
Design, Synthesis and Study of Nitrogen Monoxide Donors as Potent Hypolipidaemic and Anti-Inflammatory Agents
}

\author{
Panagiotis Theodosis-Nobelos ${ }^{1,2, *}$, Georgios Papagiouvanis ${ }^{1,2}$, Maria Pantelidou ${ }^{1}$, \\ Panos N. Kourounakis ${ }^{2}$, Chrysoula Athanasekou ${ }^{3}$ and Eleni A. Rekka ${ }^{2, *}$ \\ 1 Department of Pharmacy, School of Health Sciences, Frederick University, Nicosia 1036, Cyprus; \\ gpapagiou@gmail.com (G.P.); hsc.pm@frederick.ac.cy (M.P.) \\ 2 Department of Pharmaceutical Chemistry, School of Pharmacy, Aristotelian University of Thessaloniki, \\ 54124 Thessaloniki, Greece; panoskur@pharm.auth.gr \\ 3 Institute of Nanoscience \& Nanotechnology, NCSR “Demokritos”, 15310 Agia Paraskevi Attikis, Athens, Greece; \\ c.athanasekou@inn.demokritos.gr \\ * Correspondence: nobelos1988@yahoo.gr (P.T.-N.); rekka@pharm.auth.gr (E.A.R.); Tel.: +30-2310997614 \\ (P.T.-N. \& E.A.R.); Fax: +30-2310997852 (P.T.-N. \& E.A.R.)
}

Academic Editors: Alessandra Montalbano, Virginia Spanò and Paola Barraja

Received: 8 November 2019; Accepted: 17 December 2019; Published: 19 December 2019

\begin{abstract}
Inflammation and oxidative stress are involved in cardiovascular diseases. Nitrogen monoxide participates in the regulation of endothelial processes. Thus, derivatives of classic nonsteroidal anti-inflammatory drugs (NSAIDs), trolox or cinnamic acids esterified with 2-(nitrooxy)ethanol were designed and studied. It was found that the nitrogen monoxide (NO) releasing activity was comparable to that of $S$-nitroso- $N$-acetylpenicillamine. The nitrooxy derivatives decreased potently lipid indices in the plasma of hyperlipidaemic rats (30-85\%). All compounds presented increased anti-inflammatory activity in vivo, inhibiting carrageenan-induced rat paw oedema as high as $76 \%$, up to six times higher than that of the parent acids. Lipoxygenase inhibitory activity was significant for most of them, although the parent molecules exerted a minor effect $\left(\mathrm{IC}_{50}>0.2 \mathrm{mM}\right)$. Those compounds incorporating an antioxidant structure inhibited rat microsomal membrane lipid peroxidation strongly and possessed radical scavenging activity. These results indicated that the described compounds could act at different targets in multifactorial diseases, further limiting the possible adverse effects of drug combinations.
\end{abstract}

Keywords: NO donors; synthesis; antioxidants; hyperlipidaemia; anti-inflammatory agents; lipoxygenase inhibition

\section{Introduction}

Oxygen-derived free radicals and inflammation are associated with a number of pathological conditions, including Alzheimer's, Parkinson's, cardiovascular, metabolic, gastrointestinal and autoimmune diseases [1].

Increased production of reactive oxygen species (ROS) can promote vascular dysfunction and atherogenesis. In patients with hyperlipidaemia and coronary artery disease, activation of NADPH oxidase and xanthine oxidase generates superoxide anion radical, contributing to oxidative stress. Oxidised low density lipoprotein cholesterol (LDL) is atherogenic. Hypercholesterolemia upregulates angiotensin II type 1 (AT1) receptors, further enhancing oxidative stress and vasoconstriction [2].

Classical non-steroidal anti-inflammatory drugs (NSAIDs) are widely used, although the produced non selective cyclooxygenase (COX) -1 and -2 inhibition is associated with gastric and renal 
complications [3]. Lipoxygenase (LOX) inhibitors can exert anti-inflammatory activity and limit the undesirable effects of COX inhibition [3]. The role of lipoxygenases on the generation of atherosclerotic plaques [4,5] and their implication in the inflammation of lipid tissue [6] is under investigation. Therefore, the interrelation of inflammation, hyperlipidaemia and ROS production has become evident.

Nitrogen monoxide (NO) participates in neuronal plasticity, memory and learning processes, vascular tone, inhibition of platelet aggregation and neutrophil chemotaxis. In cases of inflammatory and oxidative conditions, like diabetes, hypertension, hypercholesterolemia and atherosclerosis, uncoupling of nitrogen oxide synthase (NOS), propagation of oxidative stress, neutrophil and macrophage infiltration are observed [7]. The latter phenomena could be reversed by the administration of hypolipidaemic agents that could limit endothelial NOS uncoupling [8]. Furthermore, the reduction of the gastrointestinal toxicity of NSAIDs with the incorporation of NO releasing moieties has been reported [3,9].

In view of the aforementioned evidence, adequate antioxidant and/or anti-inflammatory activity, combined with NO releasing potential could be considered useful in the treatment of complex diseases, such as those affecting the cardiovascular system. Therefore, we designed and synthesised a series of 2-(nitrooxy)ethanol esters with classic NSAIDs (compounds 1,3-5), the well-known antioxidant trolox (( \pm -6-hydroxy-2,5,7,8-tetramethylchromane-2-carboxylic acid), compound 9 and cinnamic acid ((E)-3-phenylacrylic acid) compound 6, or BHCA ((E)-3-(3,5-di-tert-butyl-4-hydroxyphenyl)acrylic acid), compounds 7 , a cinnamic acid derivative possessing the molecular characteristics of both butylated hydroxytoluene (BHT) and cinnamic acid (Figure 1). 2-(Nitooxy)ethanol was selected, since we found that a chain of two carbon atoms between the carboxylate and the nitric ester groups favoured activity [9]. Two more compounds, one representing the NSAIDs group (2) and one from the antioxidant acids set (8), with a $p$-nitrophenyl moiety, were synthesised for comparison, due to their comparable lipophilic and electron withdrawing character.

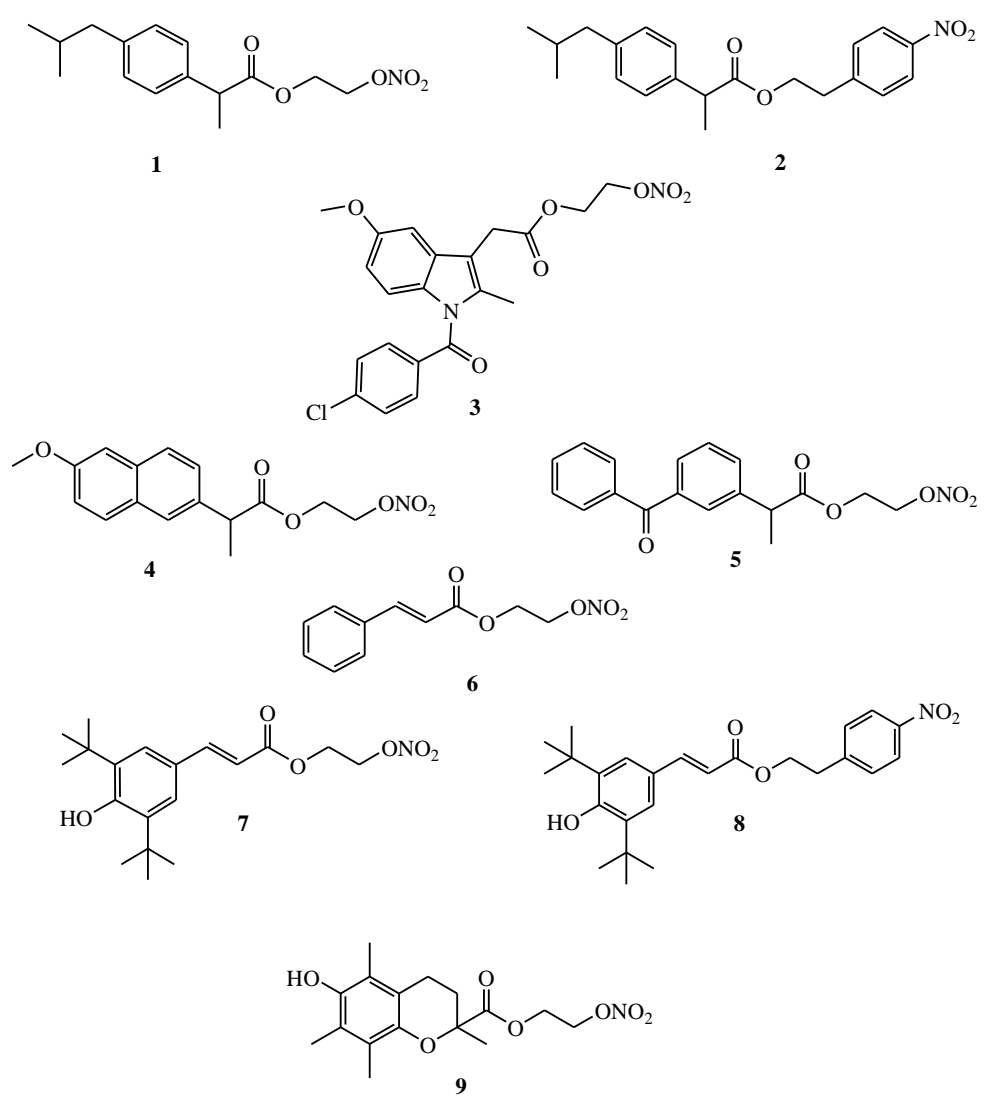

Figure 1. Structures of the synthesised compounds. 
Compound $\mathbf{1}$ is reported in the literature [10] as an agent promoting wound healing, without synthetic details or structure characterisation. Compound $\mathbf{5}$ has been synthesised previously [11] via a different method (nitration of 2-bromoethanol with a $70 \% \mathrm{HNO}_{3}-95 \% \mathrm{H}_{2} \mathrm{SO}_{4}$ mixture gave nitrooxyethyl bromide, which yielded the final product after condensation with ketoprofen in the presence of $\mathrm{Cs}_{2} \mathrm{CO}_{3}$ ) and was tested for anti-proliferative activity using prostate cancer cells. All other compounds are novel. Compounds $\mathbf{1}, \mathbf{2 , 5}$ and $\mathbf{9}$ are racemic.

The effect of the synthesised compounds on lipidaemic indices in the plasma of hyperlipidaemic rats was examined and the NO releasing ability was determined. The antioxidant activity, expressed as the inhibition of rat hepatic microsomal membrane lipid peroxidation, as well as the interaction with the stable radical 2,2-diphenyl-1-picrylhydrazyl (DPPH) was evaluated for selected compounds. The effects on carrageenan-induced rat paw oedema and the in vitro activity of soybean lipoxygenase were examined.

\section{Results and Discussion}

\subsection{Synthesis}

As shown in Scheme 1, the starting material $\mathbf{i}$ was prepared using silver nitrate and 2-chloroethanol [9]. Compound $\mathbf{i}$ or 2-(4-nitrophenyl)ethanol was esterified with $( \pm)$ ibuprofen (compounds 1, 2), indomethacin (compound 3), (+) naproxen (compound 4), ( \pm ) ketoprofen (compound 5), cinnamic acid (compound 6), BHCA (compounds 7, 8) trolox (compound 9) using three methods, in good yields (up to 80\%). An excess of the corresponding alcohol was used due to the electron withdrawing effect of the nitrooxy group. The application of method $\mathbf{A}$ for the synthesis of the trolox derivative 9 failed to give the expected product, possibly due to steric reasons. Compound 9 was obtained (yield 74\%) using CDI (method B), since this reaction is less sterically hindered.

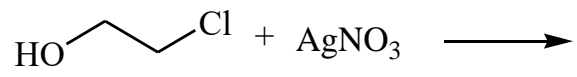<smiles>O=[N+]([O-])OC(I)CO</smiles><smiles>[R]C(=O)[OH2+]</smiles><smiles>O=[N+]([O-])c1ccc(CCO)cc1</smiles>

A) $\mathrm{DCC} / \mathrm{DMAP} / \mathrm{CHCl}_{3}$ B) $\mathrm{CDI} / \mathrm{THF}$ C) oxalylchloride/ $\mathrm{Et}_{3} \mathrm{~N} / \mathrm{CHCl}_{3}$<smiles>[R]C(C)=O</smiles><smiles>[R]C(=O)OCCO[N+](=O)[O-]</smiles><smiles>[AsH][AsH2]</smiles>

or<smiles>Cc1ccc([N+](=O)[O-])cc1</smiles>

2,8

Scheme 1. Synthesis of compounds 1-9. A) Compounds 1, 3, 4, 5, 7, 8: Acid (1 mmol), 2-nitroxy-ethanol (2 mmol) or 2-(4-nitrophenyl)ethanol (2 mmol, compound 8), DCC (1.5 mmol), DMAP (0.1 mmol), in $\mathrm{CHCl}_{3}, 4 \mathrm{~h}$, r.t. B) Compound 9: Trolox (1 mmol), CDI, (1.1 mmol), tetrahydrofuran, stirring, $4 \mathrm{~h}$. 2-Nitrooxy-ethanol (2 mmol), 24 h, r.t. C) Compounds 2, 6. Acid (1 mmol), oxalylchloride (3 mmol), $0-4{ }^{\circ} \mathrm{C}, \mathrm{CHCl}_{3}$, stirring, $3 \mathrm{~h}$. 2-Nitrooxy-ethanol ( $\left.2 \mathrm{mmol}\right)$, triethylamine (1.1 mmol), $3 \mathrm{~h}$, r.t.

\subsection{Hypolipidaemic Effect}

The pleiotropic effects of statins, used as hypolipidaemic drugs, include antioxidant ability and direct increase of eNOS activity, in addition to inhibition of 3-hydroxy-3-methylglutaryl coenzyme A (HMG-CoA) reductase [12]. Considering the aforementioned, compounds 1, 3-7 and 9 were tested for anti-dyslipidaemic activity in Triton-induced hyperlipidaemia in rats. The systemic administration 
of Triton-WR1339 (tyloxapol) to rats induces a biphasic elevation of plasma cholesterol, atherogenic VLDL cholesterol and LDL cholesterol, as well as triglyceride levels. In phase I, plasma lipid levels increased sharply, after $24 \mathrm{~h}$. Agents shown to be active in phase I are considered to interfere with cholesterol biosynthesis $[13,14]$. Results are shown in Table 1.

Table 1. Effect of the nitrooxy compounds, simvastatin, ibuprofen and ketoprofen on Triton WR1339 (tyloxapol) induced hyperlipidaemia.

\begin{tabular}{ccccc}
\hline \multirow{2}{*}{ Compound } & \multirow{2}{*}{ Dose $(i . p).(\mu \mathrm{mol} / \mathbf{k g})$} & \multicolumn{3}{c}{$\%$ Reduction } \\
\cline { 2 - 5 } & & TC $^{\mathbf{a}}$ & TG $^{\mathbf{b}}$ & LDL-C $^{\mathbf{c}}$ \\
\hline $\mathbf{1}$ & 150 & $62.2^{* *}$ & $30.1^{* *}$ & $80.0^{*}$ \\
$\mathbf{3}$ & 150 & $71.7^{* *}$ & $31.8^{* *}$ & $62.3^{*}$ \\
$\mathbf{4}$ & 150 & $78.2^{* * *}$ & $38.9^{* * *}$ & $84.6^{* * *}$ \\
$\mathbf{5}$ & 150 & $46.6^{* *}$ & $40.2^{* * *}$ & $57.8^{* * *}$ \\
$\mathbf{6}$ & 150 & $70.9^{* * *}$ & $54.4^{* * *}$ & $74.8^{* * *}$ \\
$\mathbf{7}$ & 150 & $65.5^{* *}$ & $45.7^{* * *}$ & $60.6^{*}$ \\
$\mathbf{9}$ & 150 & $55.4^{* * *}$ & $30.0^{* * *}$ & $65.0^{* * *}$ \\
Simvastatin & 150 & $73.0^{* * *}$ & - & $70.0^{* * *}$ \\
Ibuprofen & 300 & $41.0^{* * *}$ & $38.0^{* * *}$ & $41.6^{* * *}$ \\
Naproxen & 500 & $53.0^{* * *}$ & $43.5^{* * *}$ & $25.5^{* * *}$ \\
\hline
\end{tabular}

a TC: Total cholesterol; ${ }^{\text {b }}$ TG: Triglycerides; ${ }^{\mathrm{c}}$ LDL-C: LDL cholesterol. Tyloxapol: $200 \mathrm{mg} / \mathrm{kg}$, i.p. Significant difference from hyperlipidaemic control group: ${ }^{*} p<0.01,{ }^{* *} p<0.005,{ }^{* * *} p<0.001$ (Student's $t$ test).

All tested compounds strongly decreased lipidaemic indices, especially cholesterol levels (LDL and total, 61-85\% and 55.4-78.2\%, respectively). The animals appeared normal, macroscopically and by autopsy, $24 \mathrm{~h}$ post administration. The activity of compounds was higher than that of the relevant parent acids at a much lower dose. In this experiment, it was confirmed that, although simvastatin profoundly lowered cholesterol, being comparable to the synthesised compounds, it had no effect on plasma triglyceride levels. Indeed, it has been reported that statins mainly lower serum LDL levels, whereas a serum triglyceride decrease is a minor effect [15]. The synthesised compounds significantly decreased triglyceride plasma concentrations as well (30-54.4\%).

\subsection{Nitrogen Monoxide Release}

The ability of compounds 1,3-7 and 9 to release NO in vitro, at different concentrations is shown in Table 2. Compounds $\mathbf{2}$ and $\mathbf{8}$ were not included, because they were not possible NO donors. A linear increase in the amount of released $\mathrm{NO}$ was observed with increasing compound concentration.

With the small deviation of compounds 4 and 7, compounds showed similar NO donating ability reaching up to $24 \mu \mathrm{M} \mathrm{NO} / 100 \mu \mathrm{M}$ compound. NO release from $S$-nitroso- $N$-acetylpenicillamine (SNAP), a known potent NO donor, was found to be $56.3 \mu \mathrm{M} / 100 \mu \mathrm{M}$.

Table 2. In vitro nitrogen monoxide release.

\begin{tabular}{lccccccc}
\hline \multirow{2}{*}{ Compound } & \multicolumn{7}{c}{ NO Release $(\boldsymbol{\mu M})$ /Compound } \\
\hline $\mathbf{1}$ & $\mathbf{3}$ & $\mathbf{4}$ & $\mathbf{5}$ & $\mathbf{6}$ & $\mathbf{7}$ & $\mathbf{9}$ \\
\hline $500 \mu \mathrm{M}$ & 116 & 102 & 73 & 100 & 98 & 77 & 93 \\
$250 \mu \mathrm{M}$ & 82 & 58 & 37 & 57 & 51 & 38 & 49 \\
$125 \mu \mathrm{M}$ & 40 & 28 & 17 & 26 & 22 & 17 & 23 \\
$62.5 \mu \mathrm{M}$ & 17 & 13 & 7 & 11 & 11 & 6.5 & 10 \\
$31.25 \mu \mathrm{M} 7$ & 5 & 2.5 & 4 & 5 & 2 & 3 \\
\hline
\end{tabular}

All determinations (using the Griess reagent) were performed at least in triplicate and the standard deviation was always within $\pm 10 \%$ of the mean value. 
Compounds with NO-releasing activity could be useful especially in cardiovascular complications. It is known that the NO precursor L-arginine reduced atherosclerosis in LDL receptor knockout hypercholesterolaemic mice, and this activity was inhibited by NOS inhibitors [16].

\subsection{Lipoxygenase Inhibitory Activity}

Lipoxygenases form the second major path of arachidonic acid metabolism. In atherogenic plaques considerable lipoxygenase activity has been observed [6], implicated in adipose tissue inflammation and atherosclerosis [17].

Although there are several lipoxygenase enzymes, it is believed that all enzymes share a common mechanism, i.e., the stereo- and region- specific peroxidation of arachidonic or linoleic acid by molecular oxygen [18]. Soybean lipoxygenase 1-B can use arachidonic acid as a substrate, with about $15 \%$ of the activity using linoleic acid.

The ability of compounds to inhibit lipoxygenase, presented as $\mathrm{IC}_{50}$ values towards soybean lipoxygenase 1-B, using linoleic acid as a substrate, after 7 min of incubation, is demonstrated in Table 3. The $\mathrm{IC}_{50}$ of nordihydroguaiaretic acid (NDGA), an antioxidant compound acting as a nonspecific inhibitor of lipoxygenase, was also included as a reference together with ibuprofen, ketoprofen and trolox. When linoleic acid was used at $1 \mathrm{mM}$, a concentration higher than the saturating substrate concentration, no inhibition was observed, under the same experimental conditions. These results indicate that the examined compounds act as competitive inhibitors of lipoxygenase, since inhibition is diminishing by increasing substrate concentration.

Table 3. Effect of compounds 1-9, ibuprofen, ketoprofen, trolox and NDGA on lipoxygenase ${ }^{\text {a }}$, and their lipophilicity $(\operatorname{cog} P)^{\mathrm{b}}$.

\begin{tabular}{ccc}
\hline Compound & $\mathrm{IC}_{\mathbf{5 0}}(\boldsymbol{\mu M})$ & $\operatorname{clog} P$ \\
\hline $\mathbf{1}$ & 46 & 4.65 \\
$\mathbf{2}$ & 24 & 5.92 \\
$\mathbf{3}$ & 107 & 5.15 \\
$\mathbf{4}$ & $>>300$ & 3.78 \\
$\mathbf{5}$ & 86 & 3.73 \\
$\mathbf{6}$ & 220 & 3.18 \\
$\mathbf{7}$ & 44 & 6.16 \\
$\mathbf{8}$ & 10.5 & 7.44 \\
$\mathbf{9}$ & 120 & 4.16 \\
Ibuprofen & 200 & \\
Ketoprofen & 220 & \\
Trolox & $>>300$ & 3.10 \\
NDGA & 1.3 & \\
\hline
\end{tabular}

a After 7 min of incubation; NDGA: nordihydroguaiaretic acid. ${ }^{\mathrm{b}} \operatorname{cog} P: \mathrm{Clog} P$ for windows v. 4.0, BioByte Corp (BioByte Corporation, Claremont, CA, U.S.A.).

The majority of the compounds showed considerable activity, except for compound 4 . Trolox derivative 9 appeared active while trolox itself had an $\mathrm{IC}_{50}$ higher than $300 \mu \mathrm{M}$. Interestingly, compounds $\mathbf{2}$ and $\mathbf{8}$ were more active than $\mathbf{1}$ and 7, respectively. At first sight, this might be attributed to the higher lipophilicity of the former compound (Table 3). However, the $\operatorname{cog} P$ value of 2 (5.92) was very close to that of compound 7 (6.16), but 2 had about double the activity of 7 . It has been reported that a 4-nitro group on a phenyl ring is among selective groups for 5-lipoxygenase inhibition [19]. Furthermore, di-tert-butylphenol derivatives, like tebufelone and darbufelone, are considered to comprise a class of dual COX-2/5-LOX inhibitors [19]. It was previously shown by us [20] that this structural moiety contributed to increased lipoxygenase inhibitory activity.

Among the nitric ester derivatives, it seems convincing that the more rigid molecules are less active. Thus, compound 4 was practically inactive, while compound 5, although equally lipophilic with 4, was quite active. Similarly, activity was lower for compounds 3 and $\mathbf{9}$. Since we showed that 
these derivatives acted as competitive inhibitors of lipoxygenase, they were expected to occupy the hydrophobic cavity at the active site, which was intended for the flexible molecules of arachidonic or linoleic acid. Therefore, more flexible, lipophilc molecules are more active than the less flexible analogues, and the least lipophilc compound 6 had low activity.

\subsection{Antioxidant and Radical Scavenging Activity}

The antioxidant activity of compounds was estimated by the inhibition of rat hepatic microsomal membrane lipid peroxidation, induced by $\mathrm{Fe}^{+2} /$ ascorbate, estimated as 2-thiobarbituric acid (TBA) reactive material, and by their interaction with the $N$-centred 1,1-diphenyl-2-picrylhydrazyl (DPPH) stable free radical [14]. Compounds 1-6 had minor antioxidant activity (inhibition of lipid peroxidation was less than $25 \%$ at $1 \mathrm{mM}$ ). The percent interaction with $\mathrm{DPPH}$ and the $\mathrm{IC}_{50}$ values of compounds 7-9 on rat hepatic microsomal membrane lipid peroxidation, after $45 \mathrm{~min}$ of incubation is shown in Table 4 .

Table 4. Interaction of compounds 7-9 and trolox, at various concentrations, with DPPH $(200 \mu \mathrm{M})^{\mathrm{a}}$ and their effect on lipid peroxidation ${ }^{b}$.

\begin{tabular}{ccccc}
\hline \multirow{2}{*}{ Compound } & \multicolumn{2}{c}{ Percent Interaction with DPPH } & \multirow{2}{*}{ Inhibition of Lipid Peroxidation IC $_{\mathbf{5 0}}(\boldsymbol{\mu} \mathbf{M})$} \\
\cline { 2 - 4 } & $\mathbf{2 0 0} \boldsymbol{\mu} \mathbf{M}$ & $\mathbf{1 0 0} \boldsymbol{\mu} \mathbf{M}$ & $\mathbf{5 0} \boldsymbol{\mu} \mathbf{M}$ & \\
\hline $\mathbf{7}$ & 87 & 49 & 21 & 41 \\
$\mathbf{8}$ & 88 & 57 & 23 & 150 \\
$\mathbf{9}$ & 92 & 90 & 55 & 2.3 \\
Trolox & 92 & 90 & 38 & 25 \\
\hline
\end{tabular}

${ }^{a}$ After 30 min of incubation. ${ }^{b}$ After 45 min of incubation. Trolox: 6-hydroxy-2,5,7,8-tetramethylchroman-2-carboxylic acid. All determinations were performed at least in triplicate and the standard deviation was always within $\pm 10 \%$ of the mean value.

Compound 9 was almost an eleven-fold stronger inhibitor of lipid peroxidation than trolox and of similar activity with trolox as a DPPH radical scavenger. It is widely known (e.g., [20]) that the antioxidant activity of phenolic compounds is due to the phenolic hydrogen abstraction and can be enhanced by the extended conjugation of the chroman ring or the cinnamic structure, resulting in radical stabilisation. This effect may be further improved by the proper lipophilicity, which would permit an effective approach to the lipid phase.

The time course of lipid peroxidation, as affected by various concentrations of 9 is shown in Figure 2. A long lag period of about $20 \mathrm{~min}$, characteristic of chain-breaking antioxidants, was observed.

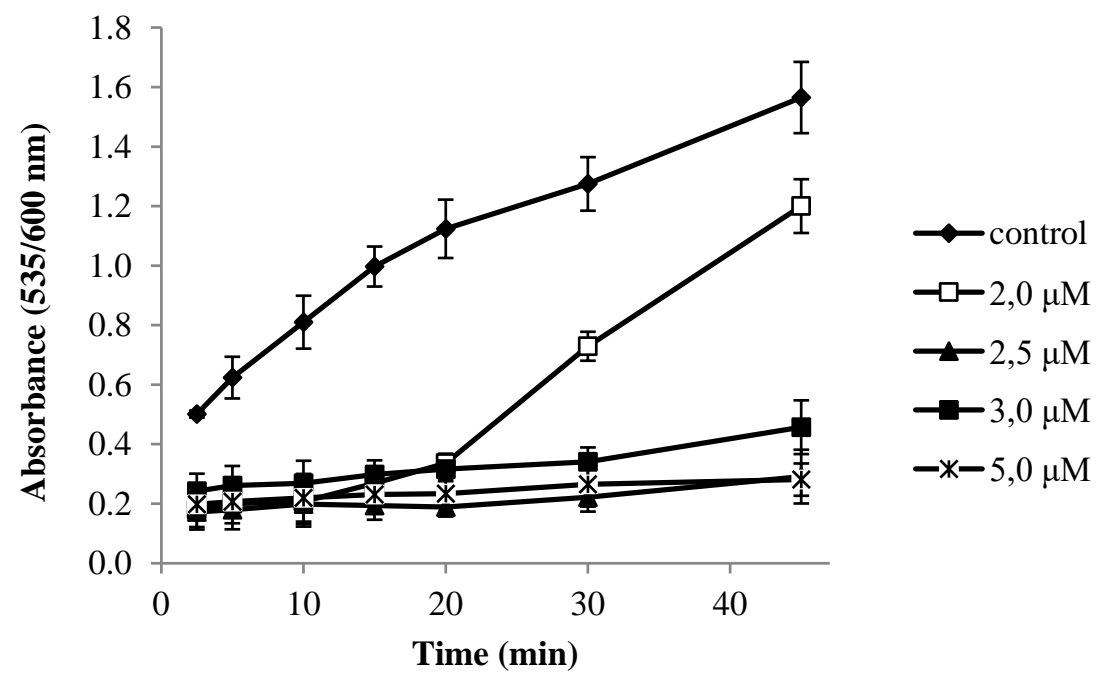

Figure 2. Effect of compound 9 (various concentrations) on the time course of lipid peroxidation. 
Compound 7 showed considerable activity in both experiments. The lower protective effect of 8 against lipid peroxidation, compared to 7 , can be attributed to the lower solubility of 8 in the aqueous environment of the experiment. Compounds 7 and 8 had about the same reducing activity in the ethanolic medium of the DPPH test. Taken together, it could be suggested that these compounds may be able to offer protection against a free radical attack by direct inhibition of lipid peroxidation as well as by inhibiting lipoxygenase, considered to play a significant contributory role to atherosclerosis [21].

\subsection{In Vivo Anti-Inflammatory Activity}

The carrageenan-induced paw oedema is a well-known and widely used model of acute inflammation. The response to carrageenan inflammation may be divided into three phases. In the first phase (after $1.5 \mathrm{~h}$ ), histamine and serotonin are released, the second phase (1.5-2.5 h after carrageenan administration) is mediated by kinins, whereas, in the third phase, more than two hours post administration, neutrophil infiltration, prostaglandin production and release of pro-inflammatory cytokines are involved [22]. In this work, oedema was measured $3.5 \mathrm{~h}$ post injection.

The effect of the synthesised compounds on acute inflammation, applying the carrageenan paw oedema model, as well as the anti-inflammatory activity of some classic NSAIDs used as a reference, is shown in Table 5.

Table 5. Effect of compounds 1-9, ibuprofen, indomethacin, ketoprofen and naproxen on carrageenan-induced rat paw oedema ${ }^{\mathrm{a}}$.

\begin{tabular}{cc}
\hline Compound & \% Oedema Reduction \\
\hline $\mathbf{1}$ & $76^{* *}$ \\
$\mathbf{2}$ & $53^{*}$ \\
$\mathbf{3}$ & $29^{* *}$ \\
$\mathbf{4}$ & $70^{* *}$ \\
$\mathbf{5}$ & $75^{* *}$ \\
$\mathbf{6}$ & $61^{* *}$ \\
$\mathbf{7}$ & $55^{* *}$ \\
$\mathbf{8}$ & $51^{* *}$ \\
$\mathbf{9}$ & $57^{* *}$ \\
Ibuprofen & $36^{*}$ \\
Indomethacin & $42^{*}$ \\
Naproxen & $11^{*}$ \\
Ketoprofen & $47^{*}$ \\
\hline
\end{tabular}

\footnotetext{
a The effect on oedema is expressed as percent oedema reduction in comparison to controls, which received carrageenan only. All compounds were administered i.p. at $0.15 \mathrm{mmol} / \mathrm{kg}$ of body weight. Significant difference from control: ${ }^{*} p<0.005,{ }^{* *} p<0.001$ (Student's $t$ test).
}

The synthesised compounds demonstrated more than $50 \%$ oedema inhibition, except for compound 3. This increase, compared with the parent NSAIDs was more than six fold higher for the naproxen derivative $\mathbf{4}$, while 1 and 5 were about two times more active than ibuprofen and ketoprofen, respectively. It seems that esterification with 2-(nitrooxy)ethanol generally increased the anti-inflammatory effect of the NSAIDs. This molecular modification also added anti-inflammatory activity to the antioxidant acids and cinnamic acid. It has been previously reported by us that esters or amides of several NSAIDs, e.g., with 2-methoxy-4-methyl-phenol or thiomorpholine, enhanced the anti-inflammatory activity of the parent molecules $[23,24]$ and that antioxidant acids such as trolox yield potent anti-inflammatory agents if they are esterified, e.g., with cinnamyl alcohol [20], while butylated hydroxytoluene (BHT) has been found devoid of any anti-inflammatory activity [9]. It has also been shown than the effect of a number of NSAID esters is not due to hydrolysis of the ester group [23]. 


\section{Materials and Methods}

\subsection{General}

All commercially available chemicals of the appropriate purity were purchased from Merck (Kenilworth, NJ, U.S.A.) or Sigma ((St. Louis, MO, U.S.A.). The IR spectra were recorded on a Perkin Elmer Spectrum BX FT-IR spectrometer (Waltham, MA, U.S.A.). The ${ }^{1} \mathrm{H}$ NMR and ${ }^{13} \mathrm{C}$ NMR spectra were recorded using a BRUKER Avance III-300 MHz (Billerica, MA, U.S.A.) or an AGILENT DD2-500 MHz ((Santa Clara, CA, U.S.A.) spectrometer. Chemical shifts were reported in $\delta$ (ppm) and signals were given as follows: $s$, singlet; $d$, doublet; $t$, triplet; $m$, multiplet. Melting points (mp) were determined with a MEL-TEMPII apparatus, Laboratory Devices, Sigma-Aldrich (Milwaukee WI, U.S.A) and were uncorrected. The microanalyses were performed on a Perkin-Elmer $2400 \mathrm{CHN}$ elemental analyser (Waltham, MA, U.S.A.). Thin-layer chromatography (TLC silica gel $60 \mathrm{~F}_{254}$ aluminium sheets, Merck (Kenilworth, NJ, U.S.A.) was used to follow the reactions and the spots were visualised under UV light.

\subsection{Synthesis}

\subsubsection{2-Nitrooxy-Ethanol [9]}

Silver nitrate (35 mmol) was added to a solution of 2-chloroethanol $(23 \mathrm{mmol})$ in acetonitrile $(40 \mathrm{~mL})$. The reaction mixture was stirred at room temperature overnight and was light protected. Then, the reaction mixture was filtered and the volatiles were removed under reduced pressure. The residue was dissolved in diethyl ether and washed with saturated $\mathrm{NaCl}$ solution. The organic layer was dried over calcium chloride, filtered, and concentrated.

Pale yellow oil, yield 16\%. IR (film) $v: 3400,2900,1630 \mathrm{~cm}^{-1} .{ }^{1} \mathrm{H} \mathrm{NMR}\left(\mathrm{CDCl}_{3}\right) \delta: 2.00(\mathrm{~s}, 1 \mathrm{H}$, $\mathrm{OH}), 3.90-4.00\left(\mathrm{t}, J=5 \mathrm{~Hz}, 2 \mathrm{H}, \mathrm{CH}_{2} \mathrm{OH}\right), 4.50-4.60\left(\mathrm{t}, J=5 \mathrm{~Hz}, 2 \mathrm{H}, \mathrm{CH}_{2} \mathrm{ONO}_{2}\right)$.

\subsubsection{General Procedures for the Synthesis of Compounds 1-9}

(A) Compounds 1, 3, 4, 5, 7, 8: The corresponding acid (1 mmol) and 2-nitrooxy-ethanol (2 mmol) or 2-(4-nitrophenyl)ethanol (2 mmol, for compound 8) were mixed in $\mathrm{CHCl}_{3}$. Then, $N, N^{\prime}$-dicyclohexylcarbodiimide (DCC, $1.5 \mathrm{mmol}$ ) and $N, N$-dimethylaminopyridine (DMAP, $0.1 \mathrm{mmol}$ ) were added and dissolved in the same solvent. The mixture was stirred for $4 \mathrm{~h}$ at ambient temperature. The final compounds were isolated with flash column chromatography using mixtures of petroleum ether and ethyl acetate.

(B) Compound 9: Trolox (1 mmol) and carbonyldiimidazole (CDI, 1,1 mmol) in tetrahydrofuran were mixed, stirred for $45 \mathrm{~min}$ and 2-nitrooxy-ethanol (2 mmol) was added and stirred for $24 \mathrm{~h}$ at ambient temperature. The solvent was distilled off, the residue was dissolved in ethyl acetate, washed with water, $5 \%$ aqueous $\mathrm{HCl}$ and $\mathrm{NaHCO}_{3}$ solutions and dried $\left(\mathrm{Na}_{2} \mathrm{SO}_{4}\right)$. The final compound was isolated with flash column chromatography using mixtures of petroleum ether and ethyl acetate as eluents.

(C) Compounds 2 and 6: The corresponding acid (1 mmol) was dissolved in $\mathrm{CHCl}_{3}$ and oxalylchloride $(3 \mathrm{mmol})$ was added at $0-4{ }^{\circ} \mathrm{C}$. After stirring for $3 \mathrm{~h}$, the volatile compounds were distilled off. 2-nitrooxy-ethanol ( $2 \mathrm{mmol})$ and triethylamine $(1.1 \mathrm{mmol})$, in the same solvent, were added at $0-4{ }^{\circ} \mathrm{C}$ and left for $3 \mathrm{~h}$. The mixture was filtered, washed with water, $5 \%$ aqueous $\mathrm{NaHCO}_{3}$, saturated $\mathrm{NaCl}$ solutions and dried $\left(\mathrm{Na}_{2} \mathrm{SO}_{4}\right)$. The final compounds were isolated with flash column chromatography with mixtures of petroleum ether and ethyl acetate as eluents.

(士)-2-(Nitrooxy)ethyl 2-(4-isobutylphenyl)propanoate (1): Flash column chromatography (petroleum ether/ethyl acetate, 40/1). Viscous transparent liquid, yield $85 \%$. IR (film) v: 3052, 3024 (C-H aromatic), 2957, 2910, 2870 (C-H alkyl), 1739 (C=O ester), 1634 (N=O), 1513 (C-C aromatic) cm ${ }^{-1}$. ${ }^{1} \mathrm{H}$ NMR $\left(\mathrm{CDCl}_{3}\right), \delta: 0.93\left(\mathrm{~d}, 6 \mathrm{H}, J=6.6 \mathrm{~Hz},-\mathrm{CH}-\left(\mathrm{CH}_{3}\right)_{2}\right), 1.53\left(\mathrm{~d}, 3 \mathrm{H}, J=7.2 \mathrm{~Hz}, \mathrm{O}=\mathrm{C}-\mathrm{CH}-\mathrm{CH}_{3}\right), 2.00-1.81$ $\left(\mathrm{m}, 1 \mathrm{H},-\mathrm{CH}_{2} \mathrm{CH}-\left(\mathrm{CH}_{3}\right)_{2}\right), 2.48\left(\mathrm{~d}, 2 \mathrm{H}, \mathrm{J}=7.1 \mathrm{~Hz},-\mathrm{CH}_{2} \mathrm{CH}-\left(\mathrm{CH}_{3}\right)_{2}\right), 3.75(\mathrm{q}, 1 \mathrm{H}, J=7.1 \mathrm{~Hz}$, 
$\left.\mathrm{O}=\mathrm{C}-\mathrm{C} H-\mathrm{CH}_{3}\right), 4.45-4.29\left(\mathrm{~m}, 2 \mathrm{H},-\mathrm{O}-\mathrm{CH}_{2}-\mathrm{CH}_{2} \mathrm{ONO}_{2}\right), 4.73-4.55\left(\mathrm{~m}, 2 \mathrm{H},-\mathrm{O}-\mathrm{CH}_{2}-\mathrm{CH}_{2} \mathrm{ONO}_{2}\right), 7.12(\mathrm{~d}$, $2 \mathrm{H}, J=8.0 \mathrm{~Hz}$, phenyl C3, C5), $7.21\left(\mathrm{~d}, 2 \mathrm{H}, J=8.0 \mathrm{~Hz}\right.$, phenyl C2, C6). ${ }^{13} \mathrm{C} \mathrm{NMR}\left(\mathrm{CDCl}_{3}\right) \delta: 18.32(1 \mathrm{C}$, $\left.\mathrm{O}=\mathrm{C}-\mathrm{CH}-\mathrm{CH}_{3}\right), 22.35\left(2 \mathrm{C},-\mathrm{CH}_{2} \mathrm{CH}-\left(\mathrm{CH}_{3}\right)_{2}\right), 30.15\left(1 \mathrm{C},-\mathrm{CH}_{2} \mathrm{CH}-\left(\mathrm{CH}_{3}\right)_{2}\right), 44.85\left(1 \mathrm{C}, \mathrm{O}=\mathrm{C}-\mathrm{CH}-\mathrm{CH}_{3}\right)$, $45.00\left(1 \mathrm{C},-\mathrm{CH}_{2} \mathrm{CH}-\left(\mathrm{CH}_{3}\right)_{2}\right), 60.35\left(1 \mathrm{C},-\mathrm{O}-\mathrm{CH}_{2}-\mathrm{CH}_{2} \mathrm{ONO}_{2}\right), 70.30\left(1 \mathrm{C},-\mathrm{O}-\mathrm{CH}_{2}-\mathrm{CH}_{2} \mathrm{ONO}_{2}\right), 127.06(2 \mathrm{C}$, phenyl C2, C6), 129.39 (2C, phenyl C3, C5), 137.05 (1C, phenyl C4), 140.78 (1C, phenyl C1), 174.34 (1C, $\mathrm{O}-\mathrm{C}=\mathrm{O}$ ). Anal. Calculated for $\mathrm{C}_{15} \mathrm{H}_{21} \mathrm{NO}_{5} \times 0.3 \mathrm{H}_{2} \mathrm{O}: \mathrm{C}, 59.91 ; \mathrm{H}, 7.24 ; \mathrm{N}, 4.66$. Found: C, 59.73; $\mathrm{H}, 7.15$; $\mathrm{N}, 4.86$.

( \pm -4-Nitrophenethyl 2-(4-isobutylphenyl)propanoate (2): Flash column chromatography (petroleum ether/ethyl acetate, 25/1 and gradually 10/1). Viscus liquid, yield 75\%. IR (nujol) $v: 1723$ (C=O ester), 1606, 1599 (C-C aromatic), $1623(\mathrm{~N}=\mathrm{O}) \mathrm{cm}^{-1} .{ }^{1} \mathrm{H}$ NMR $(\mathrm{CDCl} 3) \delta: 0.94\left(\mathrm{~d}, 6 \mathrm{H}, J=6.5 \mathrm{~Hz},-\mathrm{CH}-\left(\mathrm{CH}_{3}\right)_{2}\right)$, $1.48\left(\mathrm{~d}, 3 \mathrm{H}, J=7.1 \mathrm{~Hz}, \mathrm{O}=\mathrm{C}-\mathrm{CH}-\mathrm{CH}_{3}\right), 1.89\left(\mathrm{dt}, 1 \mathrm{H}, J=13.2,6.5 \mathrm{~Hz},-\mathrm{CH}_{2} \mathrm{CH}-\left(\mathrm{CH}_{3}\right)_{2}\right), 2.50(\mathrm{~d}$, $\left.2 \mathrm{H}, J=7.1 \mathrm{~Hz},-\mathrm{CH}_{2} \mathrm{CH}-\left(\mathrm{CH}_{3}\right)_{2}\right), 2.99\left(\mathrm{t}, 2 \mathrm{H}, J=6.2 \mathrm{~Hz},-\mathrm{O}-\mathrm{CH}_{2}-\mathrm{CH}_{2}-\mathrm{Ar}\right), 3.67(\mathrm{q}, 1 \mathrm{H}, J=7.1 \mathrm{~Hz}$, $\left.\mathrm{O}=\mathrm{C}-\mathrm{CH}-\mathrm{CH}_{3}\right), 4.50-4.23\left(\mathrm{~m}, 2 \mathrm{H},-\mathrm{O}-\mathrm{CH}_{2}-\mathrm{CH}_{2}-\mathrm{Ar}\right), 7.09(\mathrm{~d}, 2 \mathrm{H}, \mathrm{J}=7.7 \mathrm{~Hz}$, phenyl C3, C5), $7.14(\mathrm{~d}$, $2 \mathrm{H}, J=7.9 \mathrm{~Hz}$, phenyl C2, C6), $7.21(\mathrm{~d}, 2 \mathrm{H}, J=8.0 \mathrm{~Hz}$, nitrophenyl C3, C5), $8.07(\mathrm{~d}, 2 \mathrm{H}, J=8.0 \mathrm{~Hz}$, nitrophenyl C2, C6). ${ }^{13} \mathrm{C}$ NMR $\left(\mathrm{CDCl}_{3}\right) \delta: 18.22\left(1 \mathrm{C}, \mathrm{O}=\mathrm{C}-\mathrm{CH}-\mathrm{CH}_{3}\right), 22.34\left(2 \mathrm{C},-\mathrm{CH}_{2} \mathrm{CH}-\left(\mathrm{CH}_{3}\right)_{2}\right), 30.18$ $\left(1 \mathrm{C},-\mathrm{CH}_{2} \mathrm{CH}-\left(\mathrm{CH}_{3}\right)_{2}\right), 34.83\left(1 \mathrm{C}, \mathrm{O}-\mathrm{CH}_{2}-\mathrm{CH}_{2}-\right), 44.95\left(1 \mathrm{C}, \mathrm{O}=\mathrm{C}-\mathrm{CH}-\mathrm{CH}_{3}\right), 45.06\left(1 \mathrm{C},-\mathrm{CH}_{2} \mathrm{CH}-\left(\mathrm{CH}_{3}\right)_{2}\right)$, $63.93\left(1 \mathrm{C}, \mathrm{O}-\mathrm{CH}_{2}-\mathrm{CH}_{2}-\right), 123.53$ (2C, nitrophenyl $\left.\mathrm{C} 3, \mathrm{C} 5\right), 127.12(2 \mathrm{C}$, phenyl $\mathrm{C} 2, \mathrm{C} 6), 129.31(2 \mathrm{C}$, nitrophenyl C2, C6), 129.67 (2C, phenyl C3, C5), 137.39 (1C, phenyl C4), 140.73 (1C, phenyl C1), 145.68 (1C, nitrophenyl C4), 146.69 (1C, nitrophenyl C1), 174.41 (1C, O-C=O). Anal. Calculated for $\mathrm{C}_{21} \mathrm{H}_{25} \mathrm{NO}_{4} \times 0.9 \mathrm{H}_{2} \mathrm{O}: \mathrm{C}, 67.84 ; \mathrm{H}, 7.27 ; \mathrm{N}, 3.77$. Found: $\mathrm{C}, 67.86 ; \mathrm{H}, 7.46 ; \mathrm{N}, 3.74$.

2-(Nitrooxy)ethyl 2-(1-(4-chlorobenzoyl)-5-methoxy-2-methyl-1H-indol-3-yl)acetate (3): Flash column chromatography (petroleum ether/ethyl acetate, 10/1). Yellow powder, yield $50 \%, \mathrm{mp} 83-84^{\circ} \mathrm{C}$. IR (nujol) $v: 1743$ (C=O ester), 1684 ( $\mathrm{C}=\mathrm{O}$ amide), 1604, 1590 (C-C aromatic) $\mathrm{cm}^{-1} \cdot{ }^{1} \mathrm{H}$ NMR $\left(\mathrm{CDCl}_{3}\right) \delta: 2.41$ (s, $\left.3 \mathrm{H}, \mathrm{CH}_{3}-\mathrm{C}-\mathrm{N}-\right), 3.73\left(\mathrm{~s}, 2 \mathrm{H},-\mathrm{CH}_{2}-\mathrm{C}=\mathrm{O}\right), 3.87\left(\mathrm{~s}, 3 \mathrm{H},-\mathrm{O}-\mathrm{CH}_{3}\right), 4.46-4.38\left(\mathrm{~m}, 2 \mathrm{H},-\mathrm{O}-\mathrm{CH}_{2}-\mathrm{CH}_{2} \mathrm{ONO}_{2}\right)$, 4.75-4.60 (m, $\left.2 \mathrm{H},-\mathrm{O}-\mathrm{CH}_{2}-\mathrm{CH}_{2} \mathrm{ONO}_{2}\right), 6.71(\mathrm{dd}, 1 \mathrm{H}, J=9.0,2.4 \mathrm{~Hz}$, indole C6), $6.91(\mathrm{~d}, 1 \mathrm{H}, J=9.0 \mathrm{~Hz}$, indole $\mathrm{C} 7), 6.98(\mathrm{~d}, 1 \mathrm{H}, J=2.4 \mathrm{~Hz}$, indole $\mathrm{C} 4), 7.50(\mathrm{~d}, 2 \mathrm{H}, J=8.6 \mathrm{~Hz}$, chloro-benzoyl C3, C5), $7.69(\mathrm{~d}, 2 \mathrm{H}$, $J=8.6 \mathrm{~Hz}$, chloro-benzoyl C2, C6). ${ }^{13} \mathrm{C} \mathrm{NMR}\left(\mathrm{CDCl}_{3}\right) \delta: 13.27\left(1 \mathrm{C}, \mathrm{CH}_{3}-\mathrm{C}-\mathrm{N}-\right), 30.02\left(1 \mathrm{C},-\mathrm{CH}_{2}-\mathrm{C}=\mathrm{O}\right)$, 55.69 (1C, $\left.\mathrm{CH}_{3}-\mathrm{O}-\right), 60.77$ (1C, $\left.-\mathrm{O}-\mathrm{CH}_{2}-\mathrm{CH}_{2} \mathrm{ONO}_{2}\right), 70.19$ (1C, - $\left.-\mathrm{C}_{2}-\mathrm{CH}_{2} \mathrm{ONO}_{2}\right), 101.09$ (1C, indole C4), 111.74 (1C, indole C3), 111.80 (1C, indole C6), 114.98 (1C, indole C7), 129.12 (2C, chloro-benzoyl C2, C6), 130.40 (1C, indole C3a), 130.77 (1C, indole C7b), 131.17 (2C, chloro-benzoyl C3, C5), 133.79 (1C, chloro-benzoyl C1), 136.09 (1C, chloro-benzoyl C4), 139.31 (1C, indole C2), 156.08 (1C, indole C5), 168.28 $(1 \mathrm{C}$, chloro-benzoyl $\mathrm{C}=\mathrm{O}), 170.40(1 \mathrm{C}$, acetate $\mathrm{C}=\mathrm{O})$. Anal. Calculated for $\mathrm{C}_{21} \mathrm{H}_{19} \mathrm{ClN}_{2} \mathrm{O}_{7} \times 0.45 \mathrm{H}_{2} \mathrm{O}: \mathrm{C}$, $55.44 ; \mathrm{H}, 4.41 ; \mathrm{N}, 6.16$. Found: C, 55.46; H, 4.54; N, 6.06.

(+)-2-(Nitrooxy)ethyl 2-(6-methoxynaphthalen-2-yl)propanoate (4): Flash column chromatography (petroleum ether/ethyl acetate, $8 / 1$ and gradually $4 / 1$ ). White powder, yield, 55\%, mp $64-65{ }^{\circ} \mathrm{C}$. IR (nujol) v: 1727 (C=O ester), $1625(\mathrm{~N}=\mathrm{O}), 1604\left(\mathrm{C}-\mathrm{C}\right.$ aromatic) $\mathrm{cm}^{-1} .{ }^{1} \mathrm{H}$ NMR $\left(\mathrm{CDCl}_{3}\right) \delta: 1.63(\mathrm{~d}, 3 \mathrm{H}$, $\left.J=7.1 \mathrm{~Hz}, \mathrm{CH}_{3}-\mathrm{CH}-\mathrm{C}=\mathrm{O}\right), 3.95\left(\mathrm{~s}, 3 \mathrm{H},-\mathrm{O}-\mathrm{CH}_{3}\right), 4.06-3.87\left(\mathrm{~m}, 1 \mathrm{H}, \mathrm{CH}_{3}-\mathrm{CH}-\mathrm{C}=\mathrm{O}\right), 4.48-4.28(\mathrm{~m}, 2 \mathrm{H}$, $\left.\mathrm{O}-\mathrm{CH}_{2}-\mathrm{CH}_{2} \mathrm{ONO}_{2}\right), 4.70-4.54\left(\mathrm{~m}, 2 \mathrm{H}, \mathrm{O}-\mathrm{CH}_{2}-\mathrm{CH}_{2} \mathrm{ONO}_{2}\right), 7.20-7.05$ (m, 2H, naphthyl C2, C7), 7.41 (d,

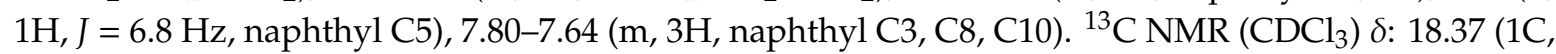
$\left.\mathrm{O}=\mathrm{C}-\mathrm{CH}-\mathrm{CH}_{3}\right), 45.20\left(1 \mathrm{C}, \mathrm{O}=\mathrm{C}-\mathrm{CH}-\mathrm{CH}_{3}\right), 55.30\left(1 \mathrm{C},-\mathrm{O}-\mathrm{CH}_{3}\right), 60.44\left(1 \mathrm{C},-\mathrm{O}-\mathrm{CH}_{2}-\mathrm{CH}_{2} \mathrm{ONO}_{2}\right), 70.28$ (1C, $-\mathrm{O}-\mathrm{CH}_{2}-\mathrm{CH}_{2} \mathrm{ONO}_{2}$ ), 105.56 (1C, naphthyl C5), 119.07 (1C, naphthyl C7), 125.97 (1C, naphthyl C10), 126.01 (1C, naphthyl C9), 127.25 (1C, naphthyl C2), 128.88 (1C, naphthyl C3), 129.26 (1C, naphthyl C8), 133.76 (1C, naphthyl C4), 139.96 (1C, naphthyl C1), 157.71 (1C, naphthyl C6), 174.27 (1C, C=O). Anal. Calculated for $\mathrm{C}_{16} \mathrm{H}_{17} \mathrm{NO}_{6} \times 0.2 \mathrm{H}_{2} \mathrm{O}: \mathrm{C}, 59.51 ; \mathrm{H}, 5.43 ; \mathrm{N}, 4.34$. Found: $\mathrm{C}, 59.51 ; \mathrm{H}, 5.17 ; \mathrm{N}, 4.65$.

( \pm )-2-(Nitrooxy)ethyl 2-(3-benzoylphenyl)propanoate (5): Flash column chromatography (petroleum ether/ethyl acetate, 5/1). Viscous transparent liquid, yield 46\%. IR (nujol) v: 1740 ( $\mathrm{C}=\mathrm{O}$ ester), 1658, $1636(\mathrm{~N}=\mathrm{O}), 1598,1581\left(\mathrm{C}-\mathrm{C}\right.$ aromatic) $\mathrm{cm}^{-1} .{ }^{1} \mathrm{H}$ NMR $\left(\mathrm{CDCl}_{3}\right), \delta: 1.59(\mathrm{~d}, 3 \mathrm{H}, J=7.1 \mathrm{~Hz}$, $\left.\mathrm{O}=\mathrm{C}-\mathrm{CH}-\mathrm{CH}_{3}\right), 3.86\left(\mathrm{q}, 1 \mathrm{H}, \mathrm{J}=7.0 \mathrm{~Hz}, \mathrm{O}=\mathrm{C}-\mathrm{CH}-\mathrm{CH}_{3}\right), 4.48-4.28\left(\mathrm{~m}, 2 \mathrm{H},-\mathrm{O}-\mathrm{CH}_{2}-\mathrm{CH}_{2} \mathrm{ONO}_{2}\right), 4.65(\mathrm{~s}$, $\left.2 \mathrm{H},-\mathrm{O}-\mathrm{CH}_{2}-\mathrm{CH}_{2} \mathrm{ONO}_{2}\right), 7.86-7.42\left(\mathrm{~m}, 9 \mathrm{H}\right.$, aromatic). ${ }^{13} \mathrm{C} \mathrm{NMR}\left(\mathrm{CDCl}_{3}\right) \delta: 19.65\left(1 \mathrm{C}, \mathrm{O}=\mathrm{C}-\mathrm{CH}-\mathrm{CH}_{3}\right)$, $45.33\left(1 \mathrm{C}, \mathrm{O}=\mathrm{C}-\mathrm{CH}-\mathrm{CH}_{3}\right), 60.35\left(1 \mathrm{C},-\mathrm{O}-\mathrm{CH}_{2}-\mathrm{CH}_{2} \mathrm{ONO}_{2}\right), 70.64\left(1 \mathrm{C},-\mathrm{O}-\mathrm{CH}_{2}-\mathrm{CH}_{2} \mathrm{ONO}_{2}\right), 128.26(2 \mathrm{C}$, 
benzoyl C3, C5), 128, 31 (1C, phenyl C2), 128,73 (2C, benzoyl C2, C6), 129, 35 (1C, phenyl C4), 130, 84 (1C, phenyl C5), 131, 22 (1C, phenyl C6), 131,74 (1C, benzoyl C4), 137,12 (1C, benzoyl C1), 140.78 (1C, phenyl C1), 142.61 (1C, phenyl C3), 175.12 (1C, O-C=O), 190,83 (1C, C=O ketone). Anal. Calculated for $\mathrm{C}_{18} \mathrm{H}_{17} \mathrm{NO}_{6} \times 0.2 \mathrm{H}_{2} \mathrm{O}: \mathrm{C}, 62.32 ; \mathrm{H}, 5.05 ; \mathrm{N}, 4.03$. Found: $\mathrm{C}, 62.32 ; \mathrm{H}, 5.13 ; \mathrm{N}, 4.19$.

(E)-2-(Nitrooxy)ethyl cinnamate (6): Flash column chromatography (petroleum ether/ethyl acetate, 40/1). Viscous transparent liquid, yield 42\%. IR (film) v: $1717(\mathrm{C}=\mathrm{O}$ ester), $1636(\mathrm{~N}=\mathrm{O})$, 1578,1496 (C-C aromatic) cm ${ }^{-1} .{ }^{1} \mathrm{H}$ NMR $\left(\mathrm{CDCl}_{3}\right), \delta: 4.68-4.46\left(\mathrm{~m}, 2 \mathrm{H},-\mathrm{O}-\mathrm{CH}_{2}-\mathrm{CH}_{2} \mathrm{ONO}_{2}\right), 4.98-4.70$ $\left(\mathrm{m}, 2 \mathrm{H},-\mathrm{O}-\mathrm{CH}_{2}-\mathrm{CH}_{2} \mathrm{ONO}_{2}\right), 6.47(\mathrm{~d}, 1 \mathrm{H}, 16.0 \mathrm{~Hz},-\mathrm{CH}-\mathrm{CH}-\mathrm{C}=\mathrm{O}), 7.53-7.40(\mathrm{~m}, 3 \mathrm{H}$, aromatic $\mathrm{C} 3, \mathrm{C} 4$, C5), 7.68-7.54 (m, 2H, aromatic $\mathrm{C} 2, \mathrm{C} 6), 7.75(\mathrm{~d}, 1 \mathrm{H}, 16.0 \mathrm{~Hz},-\mathrm{CH}-\mathrm{CH}-\mathrm{C}=\mathrm{O}) .{ }^{13} \mathrm{C} \mathrm{NMR}\left(\mathrm{CDCl}_{3}\right) \delta$ : $59.78\left(1 \mathrm{C}, \mathrm{O}-\mathrm{CH}_{2}-\mathrm{CH}_{2} \mathrm{ONO}_{2}\right), 70.44\left(1 \mathrm{C}, \mathrm{O}-\mathrm{CH}_{2}-\mathrm{CH}_{2} \mathrm{ONO}_{2}\right), 116.24$ (1C, - $\left.\mathrm{CH}-\mathrm{CH}-\mathrm{C}=\mathrm{O}\right), 126.05$ (1C, phenyl C1), 125.87 (2C, phenyl C2, C6), 126.33 (2C, phenyl C3, C5), 128.46 (1C, phenyl C4), 146.50 (1C, - $\mathrm{CH}-\mathrm{CH}-\mathrm{C}=\mathrm{O}), 167.75(1 \mathrm{C},-\mathrm{CH}-\mathrm{CH}-\mathrm{C}=\mathrm{O})$. Anal Calculated for $\mathrm{C}_{11} \mathrm{H}_{11} \mathrm{NO}_{5}: \mathrm{C}, 55.70 ; \mathrm{H}, 4.67 ; \mathrm{N}, 5.90$. Found: C, 55.28; H, 4.37; N, 5.95 .

(E)-2-(Nitrooxy)ethyl 3-(3,5-di-tert-butyl-4-hydroxyphenyl)acrylate (7): Flash column chromatography (petroleum ether/ethyl acetate, 20/1). White powder, yield 71\%, mp $80^{\circ} \mathrm{C}$. IR (nujol) $v: 3569(\mathrm{O}-\mathrm{H}), 1711$ ( $\mathrm{C}=\mathrm{O}$ ester), $1630(\mathrm{~N}=\mathrm{O}), 1596$ (C-C aromatic) $\mathrm{cm}^{-1} .{ }^{1} \mathrm{H}$ NMR $\left(\mathrm{CDCl}_{3}\right), \delta(\mathrm{ppm}): 1.48\left(\mathrm{~s}, 18 \mathrm{H},-\mathrm{CH}_{3}\right)$, 4.55-4.47 (m, 2H, O-CH $\left.-\mathrm{CH}_{2} \mathrm{ONO}_{2}\right), 4.80-4.72\left(\mathrm{~m}, 2 \mathrm{H}, \mathrm{O}-\mathrm{CH}_{2}-\mathrm{CH}_{2} \mathrm{ONO}_{2}\right), 5.59$ (s, 1H, Ar-OH), 6.32 $(\mathrm{d}, 1 \mathrm{H}, J=15.9 \mathrm{~Hz},-\mathrm{CH}=\mathrm{CH}-\mathrm{C}=\mathrm{O}), 7.40\left(\mathrm{~s}, 2 \mathrm{H}\right.$, phenyl), $7.66(\mathrm{~d}, 1 \mathrm{H}, J=15.9 \mathrm{~Hz},-\mathrm{CH}-\mathrm{CH}-\mathrm{C}=\mathrm{O}) .{ }^{13} \mathrm{C}$ $\operatorname{NMR}\left(\mathrm{CDCl}_{3}\right) \delta: 30.12\left(6 \mathrm{C}, \mathrm{C}-\left(\mathrm{CH}_{3}\right)_{3}\right), 34.32\left(2 \mathrm{C}, \mathrm{C}-\left(\mathrm{CH}_{3}\right)_{3}\right), 59.96\left(1 \mathrm{C}, \mathrm{O}-\mathrm{CH}_{2}-\mathrm{CH}_{2} \mathrm{ONO}_{2}\right), 70.76(1 \mathrm{C}$, $\left.\mathrm{O}-\mathrm{CH}_{2}-\mathrm{CH}_{2} \mathrm{ONO}_{2}\right), 113.29$ (1C, $\left.-\mathrm{CH}-\mathrm{CH}-\mathrm{C}=\mathrm{O}\right), 125.47(1 \mathrm{C}$, phenyl $\mathrm{C} 1), 125.65$ (2C, phenyl $\left.\mathrm{C} 2, \mathrm{C} 6\right)$, 136.40 (2C, phenyl C3, C5), 147.19 (1C, - CH-CH-C=O), 156.44 (1C, phenyl C4), 166.92 (1C, $-\mathrm{CH}-\mathrm{CH}-\mathrm{C}=\mathrm{O}$ ). Anal. Calculated for $\mathrm{C}_{19} \mathrm{H}_{27} \mathrm{NO}_{7}$ : C, 62.45; H, 7.45; N, 3.83. Found: $\mathrm{C}, 62.03 ; \mathrm{H}, 7.17 ; \mathrm{N}, 4.18$.

(E)-4-Nitrophenethyl 3-(3,5-di-tert-butyl-4-hydroxyphenyl)acrylate (8): Flash column chromatography (petroleum ether/ethyl acetate, 10/1). Yellow powder, yield $60 \%, \mathrm{mp} 156-157^{\circ} \mathrm{C}$. IR (nujol) $v: 3626$ (O-H), 1706 (C=O ester), $1629(\mathrm{~N}=\mathrm{O}), 1606,1591$ (C-C aromatic) $\mathrm{cm}^{-1} .{ }^{1} \mathrm{H}$ NMR $\left(\mathrm{CDCl}_{3}\right) \delta: 1.49$ (s, $\left.18 \mathrm{H},-\mathrm{CH}_{3}\right), 3.16\left(\mathrm{t}, 2 \mathrm{H}, \mathrm{O}-\mathrm{CH}_{2}-\mathrm{CH}_{2}-\mathrm{Ar}\right), 4.50\left(\mathrm{t}, 2 \mathrm{H}, \mathrm{O}-\mathrm{CH}_{2}-\mathrm{CH}_{2}-\mathrm{Ar}\right), 5.54$ (s, 1H, Ar-OH), 6.27 (d, $1 \mathrm{H}, J=15.9 \mathrm{~Hz},-\mathrm{CH}=\mathrm{CH}-\mathrm{C}=\mathrm{O}), 7.38(\mathrm{~s}, 2 \mathrm{H}$, phenyl $\mathrm{C} 2, \mathrm{C} 6), 7.46(\mathrm{~d}, 2 \mathrm{H}, J=7.5 \mathrm{~Hz}$, nitrophenyl $\mathrm{C} 2, \mathrm{C} 6), 7.66(\mathrm{~d}, 1 \mathrm{H}, J=15.9 \mathrm{~Hz},-\mathrm{CH}=\mathrm{CH}-\mathrm{C}=\mathrm{O}), 8.21\left(\mathrm{~d}, 2 \mathrm{H}, J=7.5 \mathrm{~Hz}\right.$, nitrophenyl C3, C5). ${ }^{13} \mathrm{C}$ $\operatorname{NMR}\left(\mathrm{CDCl}_{3}\right) \delta: 30.12\left(6 \mathrm{C}, \mathrm{C}-\left(\mathrm{CH}_{3}\right)_{3}\right), 34.31\left(2 \mathrm{C}, \mathrm{C}-\left(\mathrm{CH}_{3}\right)_{3}\right), 35.13\left(1 \mathrm{C}, \mathrm{O}-\mathrm{CH}_{2}-\mathrm{CH}_{2}-\mathrm{Ar}\right), 63.64(1 \mathrm{C}$, $\left.\mathrm{O}-\mathrm{CH}_{2}-\mathrm{CH}_{2}-\mathrm{Ar}\right), 113.89$ (1C, $\left.-\mathrm{CH}-\mathrm{CH}-\mathrm{C}=\mathrm{O}\right), 123.60$ (2C, phenyl C2, $\left.\mathrm{C} 6\right), 125.51$ (2C, nitrophenyl C3, C5), 125.53 (1C, phenyl C1), 129.76 (2C, nitrophenyl C2, C6), 136.40 (2C, phenyl C3, C5), 145.89 (1C, - $\mathrm{CH}-\mathrm{CH}-\mathrm{C}=\mathrm{O}$ ), 146.52 (1C, nitrophenyl C4), 146.87 (1C, nitrophenyl C1), 156.32 (1C, phenyl C4), 167.20 $(1 \mathrm{C},-\mathrm{CH}-\mathrm{CH}-\mathrm{C}=\mathrm{O})$. Anal. Calculated for $\mathrm{C}_{25} \mathrm{H}_{31} \mathrm{NO}_{5}: \mathrm{C}, 70.57 ; \mathrm{H}, 7.34 ; \mathrm{N}, 3.29$. Found: $\mathrm{C}, 70.34 ; \mathrm{H}$, $7.67 ; \mathrm{N}, 3.51$.

( \pm )-2-(Nitrooxy)ethyl 6-hydroxy-2,5,7,8-tetramethylchroman-2-carboxylate (9): Flash column chromatography (petroleum ether/ethyl acetate, 40/1). White powder, yield $54 \%$, mp $95-97^{\circ} \mathrm{C}$. IR (nujol) v: 3532 (O-H), 1741 (C=O ester), 1649, $1634(\mathrm{~N}=\mathrm{O}) \mathrm{cm}^{-1} .{ }^{1} \mathrm{H}$ NMR $\left(\mathrm{CDCl}_{3}\right), \delta$ (ppm):1.65 (s, 3H, chromane $\mathrm{C} 1), 2.00-1.86\left(\mathrm{~m}, 1 \mathrm{H}\right.$, chromane $\mathrm{C} 2$ axial), 2.20, 2.19, 2.09 (3s, 9H, $-\mathrm{CH}_{3}$ aromatic), 2.52-2.41 (m, 1H, chromane $\mathrm{C} 2$ equatorial), 2.74-2.53 (m, 2H, chromane $\mathrm{C} 3), 4.44-4.24(\mathrm{~m}, 2 \mathrm{H}$, $\left.-\mathrm{O}-\mathrm{CH}_{2}-\mathrm{CH}_{2} \mathrm{ONO}_{2}\right), 4.60-4.47\left(\mathrm{~m}, 2 \mathrm{H},-\mathrm{O}-\mathrm{CH}_{2}-\mathrm{CH}_{2} \mathrm{ONO}_{2}\right) .{ }^{13} \mathrm{C} \mathrm{NMR}\left(\mathrm{CDCl}_{3}\right) \delta: 11.17,11.71,12.13$ (3C, $-\mathrm{CH}_{3}$ aromatic), 20.87 (1C, chromane $\left.\mathrm{C} 3\right), 25.32\left(1 \mathrm{C}\right.$, chromane $\left.\mathrm{C} 1-\mathrm{CH}_{3}\right), 30.61$ (1C, chromane $\left.\mathrm{C} 2\right)$, $60.46\left(1 \mathrm{C}, \mathrm{O}-\mathrm{CH}_{2}-\mathrm{CH}_{2} \mathrm{ONO}_{2}\right), 70.28\left(1 \mathrm{C}, \mathrm{O}-\mathrm{CH}_{2}-\mathrm{CH}_{2} \mathrm{ONO}_{2}\right), 77.19$ (1C, chromane C1), 116.80 (1C, chromane C4), 118.42 (1C, chromane C7), 121.24 (1C, chromane C8), 122.64 (1C, chromane C5), 145.40 (1C, chromane C6), 145.47 (1C, chromane C9), $173.63(1 \mathrm{C}, \mathrm{C}=\mathrm{O})$. Anal. Calculated for $\mathrm{C}_{16} \mathrm{H}_{21} \mathrm{NO}_{7}$ x2 $\mathrm{H}_{2} \mathrm{O}: \mathrm{C}, 51.20 ; \mathrm{H}, 6.71 ; \mathrm{N}, 3.73$. Found: C, 51.31; H, 6.47; N, 3.87 .

\subsection{Biological Evaluation}

K-Carrageenan and lipoxygenase type I-B from soybean were purchased from Sigma (St. Louis, MO, U.S.A.). For the in vivo experiments, Wistar rats (180-220 g, 3-4 months old) were kept in the Centre of the School of Veterinary Medicine (EL54 BIO42), Aristotelian University of 
Thessaloniki, which is registered by the official state veterinary authorities (presidential degree 56/2013, in harmonization with the European Directive 2010/63/EEC). The experimental protocols were approved by the Animal Ethics Committee of the Prefecture of Central Macedonia (no. 270079/2500).

\subsubsection{Effect on Plasma Cholesterol, Triglyceride and LDL-Cholesterol Levels}

Hyperlipidaemia was induced by the i.p. administration of Triton WR $1339(200 \mathrm{mg} / \mathrm{kg})$ to rats. The examined compounds $(0.15 \mathrm{mmol} / \mathrm{kg})$ were administered i.p. one hour later. Blood was taken from the aorta after $24 \mathrm{~h}$, for the determination of plasma total cholesterol, LDL-cholesterol and triglyceride concentrations, using commercial kits [13].

\subsubsection{In Vitro NO Release}

Due to their poor aqueous solubility, compounds 1, 3-7 and 9 were dissolved in $7 / 3(v / v)$ mixture of $\mathrm{DMSO} /$ water at various concentrations and incubated overnight at room temperature in the presence of cadmium. S-nitroso- $N$-acetylpenicillamine (SNAP) was dissolved either in DMSO/water 7/3 or in water and treated as above.

Aliquots were taken from each sample and added to an equal volume of $\mathrm{N}$-naphthylaminoethylamine $(0.2 \%)$ and sulfanilamide $(2 \%)$ solution in $3 \mathrm{~N}$ hydrochloric acid (Griess reagent). Appropriate sodium nitrite solutions in the same DMSO/water mixture were used for the construction of the standard curve and values were identical to those obtained with aqueous solutions. Nitric oxide release was estimated spectrophotometrically $(540 \mathrm{~nm})$ [9]. NO release from SNAP (100 $\mu \mathrm{M}$ in DMSO/water $7 / 3$ and in water) was found to be 56.3 and $56.7 \mu \mathrm{M}$, respectively, further verifying that the addition of DMSO did not influence the experiment.

\subsubsection{In Vitro Evaluation of Lipoxygenase Activity}

The reaction mixture contained the examined compounds (in absolute ethanol, 1-300 $\mu \mathrm{M}$ ), soybean lipoxygenase (in saline, $250 \mathrm{u} / \mathrm{mL}$ ) and sodium linoleate $(100 \mu \mathrm{M})$, in Tris- $\mathrm{HCl}$ buffer, $\mathrm{pH}$ 9.0. The reaction was monitored for $7 \mathrm{~min}$ at $28^{\circ} \mathrm{C}$, recording the absorbance at $234 \mathrm{~nm}$. Nordihydroguaiaretic acid (NDGA) was used as a reference.

For the estimation of the type of inhibition, the described experiments were repeated, using sodium linoleate at a concentration $(1 \mathrm{mM})$ higher than the saturating substrate concentration [23].

\subsubsection{In Vitro Lipid Peroxidation}

The peroxidation of heat-inactivated $\left(90^{\circ}, 90 \mathrm{~s}\right)$ rat liver microsomal fraction was induced by ascorbic acid $(0.2 \mathrm{mM})$ and ferrous sulphate $(10 \mu \mathrm{M})$. The studied compounds, in dimethylsulfoxide, were added at concentrations $1 \mu \mathrm{M}-1 \mathrm{mM}$. Aliquots were taken from the incubation mixture $\left(37^{\circ} \mathrm{C}\right)$ for $45 \mathrm{~min}$. Lipid peroxidation was assessed spectrophotometrically $(535 / 600 \mathrm{~nm})$ as 2-thiobarbituric acid reactive material. All compounds and solvents were found not to interfere with the assay [25].

\subsubsection{In Vitro Interaction with the Stable Radical 1,1-Diphenyl-2-Picrylhydrazyl (DPPH)}

Compounds (in absolute ethanol, final concentrations 25-200 $\mu \mathrm{M}$ ) were added to an ethanolic solution of DPPH (final concentration $200 \mu \mathrm{M})$ at room temperature $\left(22 \pm 2{ }^{\circ} \mathrm{C}\right)$. Absorbance $(517 \mathrm{~nm})$ was recorded after $30 \mathrm{~min}$.

\subsubsection{Carrageenan-Induced Paw Oedema}

The tested compounds (in water with a few drops of Tween 80$)$ were given i.p. $(0.15 \mathrm{mmol} / \mathrm{kg})$ to rats, just after the i.d. injection of $0.1 \mathrm{~mL}$ of an aqueous carrageenan solution $(1 \% w / v)$ in the hind paw of rats. The produced oedema, after $3.5 \mathrm{~h}$, was estimated as paw weight increase [24]. 


\section{Conclusions}

There are a number of reports in the literature concerning derivatives of NSAIDs with NO releasing ability. Those compounds were designed mainly as gastroprotective agents, counteracting the gastric irritation caused by the classical NSAIDs [26]. In addition, various derivatives of antioxidants, such as butylated hydroxytoluene, vitamin E and trolox, acting as NO donors, have been synthesised and tested as vasodilating agents in in vitro experiments [27-29].

In the present investigation, the designed new compounds were synthesised and tested for hypolipidaemic activity in vivo, a process that is close to the medical practice. This activity is also correlated with their in vivo effect on acute inflammation, their ability to act as NO donors, lipoxygenase inhibitors and antioxidants in vitro. Among the tested compounds, the naproxen derivative 4 demonstrated strong hypolipidaemic ( $80 \%$ reduction of total cholesterol) and anti-inflammatory (70\% reduction of rat paw oedema) activity. The butylated hydroxycinnamic acid analogue 7 is a potent hypolipidaemic (66\% reduction of total cholesterol), anti-inflammatory (55\% reduction of rat paw oedema) and antioxidant (lipid peroxidation inhibition, $\mathrm{IC}_{50} 41 \mu \mathrm{M}$ ) compound. The ester of butylated hydroxycinnamic acid with 4-nitrophenylethyl alcohol 8 inhibits lipoxygenase $\left(\mathrm{IC}_{50} 10.5 \mu \mathrm{M}\right)$ and is an anti-inflammatory agent (51\% reduction of rat paw oedema).

The successful combination of antioxidant, anti-inflammatory and NO releasing activities is important for compounds that would acquire a series of biological properties able to prevent or restore a number of pathological changes in conditions like cardiovascular and inflammatory disorders. We hope that the described multifunctional compounds may assist towards the development of agents against multicausal disorders, which otherwise would require multiple drug therapies to address the various pathological disturbances.

Author Contributions: Investigation, P.T.-N., G.P., C.A.; Supervision, E.A.R.; Writing-review \& editing, M.P. and P.N.K. All authors have read and agreed to the published version of the manuscript.

Funding: This research received no external funding.

Acknowledgments: G. Papagiouvannis acknowledges the General Secretariat for Research and Technology (GSRT) of Greece and the Hellenic Foundation for Research and Innovation (HFRI) for a grant supporting his $\mathrm{PhD}$ research.

Conflicts of Interest: The authors declare no conflicts of interest.

\section{References}

1. Sánchez, A.; Calpena, A.C.; Clares, B. Evaluating the oxidative stress in inflammation: Role of melatonin. Int. J. Mol. Sci. 2015, 16, 16981-17004. [CrossRef] [PubMed]

2. Nickenig, G.; Bäumer, A.T.; Temur, Y.; Kebben, D.; Jockenhovel, F.; Bohm, M. Statin-sensitive dysregulated AT1 receptor function and density in hypercholesterolemic men. Circulation 1999, 100, 2131-2134. [CrossRef] [PubMed]

3. Tziona, P.; Theodosis-Nobelos, P.; Rekka, E.A. Medicinal Chemistry approaches of controlling gastrointestinal side effects of non-steroidal anti-inflammatory drugs. Endogenous protective mechanisms and drug design. Med. Chem. 2017, 13, 408-420. [CrossRef] [PubMed]

4. Singh, N.K.; Rao, G.N. Emerging role of 12/15-Lipoxygenase (ALOX15) in human pathologies. Lipid Res. 2019, 73, 28-45. [CrossRef] [PubMed]

5. Hofker, M. Lipoxygenases at the heart of atherosclerosis susceptibility. Eur. J. Hum. Genet. 2004, 12, 601-602. [CrossRef] [PubMed]

6. Cole, B.K.; Lieb, D.C.; Dobrian, A.D.; Nadler, J.L. 12- and 15-lipoxygenases in adipose tissue inflammation. Prostaglandins Other Lipid Mediat. 2013, 84, 104-105. [CrossRef]

7. Förstermann, U.; Sessa, W.C. Nitric oxide synthases: Regulation and function. Eur. Heart J. 2012, 33, 829-837. [CrossRef]

8. Wenzel, P.; Daiber, A.; Oelze, M.; Brandt, M.; Closs, E.; Xu, J.; Thum, T.; Bauersachs, J.; Ertl, G.; Zou, M.H.; et al. Mechanisms underlying recoupling of eNOS by HMG-CoA reductase inhibition in a rat model of streptozotocin-induced diabetes mellitus. Atherosclerosis 2007, 198, 65-76. [CrossRef] 
9. Ziakas, G.N.; Rekka, E.A.; Gavalas, A.M.; Eleftheriou, P.T.; Tsiakitzis, K.C.; Kourounakis, P.N. Nitric oxide releasing derivatives of tolfenamic acid with anti-inflammatory activity and safe gastrointestinal profile. Bioorg. Med. Chem. 2005, 13, 6485-6492. [CrossRef]

10. Kaushal, M.; Kutty, N.G.; Rao, C.M. Nitrooxyethylation reverses the healing-suppressant effect of ibuprofen. Mediat. Inflamm. 2006, 2006, 24396. [CrossRef]

11. Bézière, N.; Goossens, L.; Pommery, J.; Vezin, H.; Touati, N.; Hénichart, J.P.; Pommery, N. New NSAIDs-NO hybrid molecules with antiproliferative properties on human prostatic cancer cell lines. Bioorg. Med. Chem. Lett. 2008, 18, 4655-4657. [CrossRef] [PubMed]

12. Schulz, E.; Anter, E.; Keaney, F. Oxidative stress, antioxidants, and endothelial function. Curr. Med. Chem. 2004, 11, 1093-1104. [CrossRef] [PubMed]

13. Tooulia, K.K.; Theodosis-Nobelos, P.; Rekka, E.A. Thiomorpholine derivatives with hypolipidemic and antioxidant activity. Arch. Pharm. (Weinheim) 2015, 348, 629-634. [CrossRef] [PubMed]

14. Korolenko, T.A.; Tuzikov, F.V.; Vasil'eva, E.D.; Cherkanova, M.S.; Tuzikova, N.A. Fractional composition of blood serum lipoproteins in mice and rats with Triton WR 1339-induced lipemia. Bull. Exp. Biol. Med. 2010, 149, 567-570. [CrossRef]

15. Branchi, A.; Fiorenza, A.M.; Rovellini, A.; Torri, A.; Muzio, F.; Macor, S.; Sommariva, D. Lowering effects of four different statins on serum triglyceride level. Eur. J. Clin. Pharmacol. 1999, 55, 499-502. [CrossRef]

16. Aji, W.; Ravalli, S.; Szabolcs, M.; Jiang, X.C.; Sciacca, R.R.; Michler, R.E.; Cannon, P.J. L-arginine prevents xanthoma development and inhibits atherosclerosis in LDL receptor knockout mice. Circulation 1997, 95, 430-437. [CrossRef]

17. Folcik, V.A.; Nivar-Aristy, R.A.; Krajewski, L.P.; Cathcart, M.K. Lipoxygenase contributes to the oxidation of lipids in human atherosclerotic plaques. J. Clin. Investig. 1995, 96, 504-510. [CrossRef]

18. Bushnell, E.A.C.; Berryman, V.E.J.; Gauld, J.W.; Boyd, R.J. The importance of the MM environment and the selection of the QM method in QM/MM calculations: Applications to enzymatic reactions. In Advances in Protein Chemistry and Structural Biology; Karabencheva-Christova, T., Ed.; Elsevier: Amsterdam, The Netherlands, 2015; Volume 100, Chapter 6.

19. Jacob, P.J.; Manju, S.L.; Ethiraj, K.R.; Elia, G. Safer anti-inflammatory therapy through dual COX-2/5-LOX inhibitors: A structure-based approach. Eur. J. Pharm. Sci. 2018, 121, 356-381.

20. Theodosis-Nobelos, P.; Kourounakis, P.N.; Rekka, E.A. Anti-inflammatory and hypolipidemic effect of novel conjugates with trolox and other antioxidant acids. Med. Chem. 2017, 13, 214-225. [CrossRef]

21. Mashima, R.; Okuyama, T. The role of lipoxygenases in pathophysiology; new insights and future perspectives. Redox Biol. 2015, 6, 297-310. [CrossRef]

22. Di Rosa, M.; Giroud, J.P.; Willoughby, D.A. Studies on the mediators of the acute inflammatory response induced in rats in different sites by carrageenan and turpentine. J. Pathol. 1971, 104, 15-29. [CrossRef] [PubMed]

23. Theodosis-Nobelos, P.; Tziona, P.; Poptsis, A.; Athanasekou, C.; Kourounakis, P.N.; Rekka, E.A. Novel polyfunctional esters of ibuprofen and ketoprofen with hypolipidemic, lipoxygenase inhibitory and enhanced anti-inflammatory activity. Med. Chem. Res. 2017, 26, 461-472. [CrossRef]

24. Theodosis-Nobelos, P.; Kourti, M.; Gavalas, A.; Rekka, E.A. Amides of non-steroidal anti-inflammatory drugs with thiomorpholine can yield hypolipidemic agents with improved anti-inflammatory activity. Bioorg. Med. Chem. Lett. 2016, 26, 910-913. [CrossRef] [PubMed]

25. Tsiakitzis, K.C.; Papagiouvannis, G.; Theodosis-Nobelos, P.; Tziona, P.; Kourounakis, P.N.; Rekka, E.A. Synthesis, antioxidant and anti-inflammatory effects of antioxidant acid amides with GABA and n-acyl-pyrrolidin-2-ones. Curr. Chem. Biol. 2017, 11, 127-139. [CrossRef]

26. Gund, M.; Gaikwad, P.; Borhade, N.; Burhan, A.; Desai, D.C.; Sharma, A.; Dhiman, M.; Patil, M.; Sheikh, J.; Thakre, G.; et al. Gastric-sparing nitric oxide-releasable 'true' prodrugs of aspirin and naproxen. Bioorg. Med. Chem. Lett. 2014, 24, 5587-5592. [CrossRef]

27. Cena, C.; Boschi, D.; Tron, G.C.; Chegaev, K.; Lazzarato, L.; Di Stilo, A.; Aragno, M.; Fruttero, R.; Gasco, A. Development of a new class of potential antiatherosclerosis agents: NO-donor antioxidants. Bioorg. Med. Chem. Lett. 2004, 14, 5971-5974. [CrossRef] 
28. López, G.V.; Batthyány, C.; Blanco, F.; Botti, H.; Trostchansky, A.; Migliaro, E.; Radi, R.; González, M.; Cerecetto, H.; Rubbo, H. Design, synthesis, and biological characterization of potential antiatherogenic nitric oxide releasing tocopherol analogs. Bioorg. Med. Chem. 2005, 13, 5787-5796. [CrossRef]

29. López, G.V.; Blanco, F.; Hernández, P.; Ferreira, A.; Piro, O.E.; Batthyány, C.; González, M.; Rubbo, H.; Cerecetto, H. Second generation of alpha-tocopherol analogs-nitric oxide donors: Synthesis, physicochemical, and biological characterization. Bioorg. Med. Chem. 2007, 15, 6262-6272. [CrossRef]

Sample Availability: Samples of the compounds are available from the authors.

(C) 2019 by the authors. Licensee MDPI, Basel, Switzerland. This article is an open access article distributed under the terms and conditions of the Creative Commons Attribution (CC BY) license (http://creativecommons.org/licenses/by/4.0/). 